\title{
INCOME TAX PREFERENCE AND R\&D INVESTMENTS OF HIGH-TECH ENTERPRISES IN CHINA
}

\section{Wunhong Su', Yi-Hao Fan ${ }^{2}$}

\author{
1 Hangzhou Dianzi University, School of Accounting, China, ORCID: 0000-0001-8086-6821, whsu@hdu.edu.cn \\ (corresponding author); \\ 2 University of Macau, Faculty of Business Administration, China, ORCID: 0000-0001-9147-3919, mc14314@umac.mo.
}

\begin{abstract}
This study explores the relationship between income tax preference and R\&D investments of high-tech enterprises. This study selects listed high-tech enterprises in China from 2013 to 2018 as samples. The empirical results show that the effective income tax rate among high-tech enterprises in China differs widely. The findings suggest that high-tech enterprises in China have to take advantage of preferential income tax, pay more attention to R\&D investments, and strive to improve $R \& D$ ability and market competitiveness. In addition, there is a significantly positive relationship between income tax preference and $R \& D$ investments of high-tech enterprises, indicating that the preferential tax rate policy and other tax incentives such as additional tax deduction increase R\&D investments of high-tech enterprises effectively.

State-owned enterprises (SOEs) are enterprises in which the state has ownership or control over its capital. The positive relation between income tax preference and $R \& D$ investments of hightech enterprises is more significant for non-SOEs. Non-SOEs have stronger governance efficiency. Therefore, SOEs should make better use of income tax preference and improve innovation enthusiasm. Moreover, this study finds a more positive relationship between income tax preference and $R \& D$ investments among high-tech enterprises in the introduction phase than in the growth and mature phases. However, the relation between income tax preference and R\&D investments is insignificant for high-tech enterprises in the decline phase. The findings seem to provide a new perspective for the life cycle characteristics of enterprises and the theoretical guidance to enterprises in phases of growth, mature and decline to develop R\&D investments better. Finally, loss enterprises or enterprises in geographical units with the innovative environment are eliminated in this study to avoid extra interference. The results remain robust, indicating that preferential income tax policies applied in high-tech enterprises are significantly and positively associated with R\&D investments.
\end{abstract}

Keywords: Income tax preference, R\&D investment, high-tech enterprises, innovation.

JEL Classification: E62, H21, H25, O31.

APA Style Citation: Su, W., \& Fan, Y.-H. (2021). Income Tax Preference and R\&D Investments of High-tech Enterprises in China. E\&M Economics and Management, 24(4), 156-173. https://doi.org/10.15240/tul/001/2021-4-010

\section{Introduction}

Science and technology contribute $87.5 \%$ to economic growth (Solow, 1957). Enterprises, especially high-tech enterprises, largely perform research and Development (R\&D) activities. Risks of R\&D activities lead to free-riding among enterprises. The income tax preference is preferred to control the free-riding because of reflecting the incentive effect of tax revenue on the economic development (Bronzini \& Piselli, 2016). Most industrialized countries implement special income tax incentives to boost the R\&D investment of enterprises (Elschner et al., 2011). The additional deduction, accelerated depreciation, and innovation box are common policies (McCutchen, 1993). For instance, 
Japan issues the schedule of fixed assets depreciation in 1951 and stimulate innovation of enterprises. Since 2003, OECD countries continually increase incentives for enterprises to the R\&D investment. China begins to offer income tax preference to R\&D investments of enterprises in the 1990s.

Most current tax incentives for enterprises in China are similar to other countries. However, the high-tech enterprises in China are subject to the corporate income tax at the reduced rate of $15 \%$, which is exclusive for high-tech enterprises in other countries such as the United States of America (Meng, 2003). According to the Administrative Measures for the Determination of High and New Technology Enterprises (2016), hightech technology enterprises are knowledgeintensive and technology-intensive economic entities. Therefore, R\&D investments of hightech enterprises vitally contribute to improving national innovations (Cao, 2009). The individual authentication policy of high-tech enterprises in China provides a research opportunity in this study to examine whether such a unique policy has any significant reference for other countries. Based on the characteristics of profitmaking purpose, enterprises attempt to gain the authentication of high-tech enterprises to enjoy tax preference by increasing the investment of R\&D and scientific and technological personnel (Kamien \& Schwartz, 1975). Therefore, tax incentives theoretically positively impact the improvement of innovation levels for high-tech enterprises.

On the one hand, tax incentives directly reduce the tax burden and raise profits for enterprises, increasing more cash flow for R\&D investments (Lu et al., 2008). On the other hand, enterprises are unnecessary to increase R\&D investments by only keeping authentication of high-tech enterprises to enjoy tax incentives. Therefore, an important issue is whether preferential tax policies continuously and effectively stimulate the innovation of high-tech enterprises. Accordingly, this study investigates whether there is a significantly positive relationship between income tax preference and R\&D investments of high-tech enterprises. Specifically, this study employs the adjusted ETR (effective tax rate) to measure the tax preference obtained by a high-tech enterprise. In addition, RDI (R\&D after eliminating the impact of scale) is introduced to measure the
R\&D investments by an enterprise. This study finds that the lower the effective income tax rate of high-tech enterprises, the higher the proportion of R\&D investment, suggesting that the preferential income tax leads to higher R\&D investments. The findings are consistent with most previous studies (e.g., Liao \& Xiao, 2018; Gu \& Wang, 2017; Yang et al., 2013).

Furthermore, this study finds that the positive relationship between income tax preference and R\&D investments of high-tech enterprises is more significant for non-SOEs than SOEs, which is consistent with the study by Piotroski and Wong (2012). This study also finds that such a positive relation is more significant for enterprises in the introduction phase than enterprises in the growth and mature phases. The enterprises in the decline phase have an insignificantly positive association between income tax preferences and R\&D investments.

The remainder of this paper is organized as follows. In the following section, an overview of income tax preferences and R\&D investments is presented. From this, the hypotheses are developed. In section 3 , the research design is described, including the various measures for the income tax preference and R\&D expenditures and the control variables used in the analyses. Section 4 presents the sample selection procedure and provides some preliminary descriptive results. Section 5 states the main results of the study. In section 6 , the sensitivity analyses are stated. Finally, the conclusions are presented in section 7 .

\section{Theoretical Analysis and Hypothesis Development 1.1 Prior Research}

Previous studies have a great dispute about whether tax incentives stimulate the improvement of R\&D investments. Czarnitzki et al. (2011) find that tax incentives increase the R\&D investment from 1997 to 1999. The tax incentive policy from 1998 to 2004 in Argentina successfully increases R\&D investments of manufacturing enterprises (Crespi et al., 2016). However, Rajagopal and Shah (1995) document that tax incentives have an insignificant impact on the R\&D investment of enterprises in Pakistan. The tax incentives also fail to effectively stimulate the R\&D investment of large-scale enterprises in Australia from 1990 to 2005 (Thomson, 2010). 
Cappelen et al. (2012) more specifically classify the technical innovation based on the strength of technological externalities and report that tax incentive significantly stimulate enterprises with product and process innovations. Hall (1993) finds that income tax preference on enterprises in the long term is more significant than that quickly. Gokhberg et al. (2014) illustrate that the tax preference policy has an insignificantly positive relation with enterprises' R\&D activities. Crespi et al. (2016) focus on manufacturing industries when exploring tax incentives and R\&D activities. However, many manufacturing industries have no much demand for R\&D activities. Zhang et al. (2016) document that the additional deduction of R\&D expenses improves the innovation efficiency of high-tech enterprises with high needs of R\&D activities. Accordingly, this study selects high-tech enterprises as samples.

The certification of high-tech enterprises is a special mechanism in China. Existing studies (e.g., Liao \& Xiao, 2018; Gu \& Wang, 2017; Wang \& Wang, 2009) of China concentrate on specific locations or industries such as the information technology industry, the software \& integration services industry, the mechanical equipment industry, and the materials industry. However, studies mainly investigate enterprises from Growth Enterprises Market (GEM), which provides a platform for technology enterprises and young enterprises to finance capital. For example, Yang et al. (2013) find that favorable income tax policies about technology innovation and R\&D expenditure significantly impact listed enterprises of GEM, especially for enterprises of high-tech industries that have a stronger desire for technology innovations.

$\mathrm{Li}$ et al. (2015) conclude that $1 \%$ of a preferential tax rate on average increases with at least $0.02 \%$ of the intensity of R\&D investments. However, such results fail to perfectly represent high-tech enterprises in China as enterprises listed in GEM are normally small. In addition, Chen et al. (2012) find that the incentive effect of preferential tax policies on the high-tech industry is insignificant. Interestingly, Lou and Xu (2009) reveal that turnover tax preference is more important than income tax preference. Zhou (2012) also finds that the preferential tax base and turnover tax incentives are more significant than the directly preferential tax rate and income tax preference for enterprises. Accordingly, the extant literature has rarely explored high-tech enterprises in China or is limited in specific areas that likely lack the representativeness of whole Chinese high-tech enterprises.

\subsection{Hypothesis Development}

Based on the tax reduction theory proposed by the supply-side and the Laffer curve proposed by Laffer (2004), the inverted U-shaped curve depicts the relation between tax rate and tax revenue. Before point $H$, there is a positive relationship between tax rate and tax revenue. However, beyond point $\mathrm{H}$ and entering into the 'tax penalty area', the government's tax revenue decreases conversely because of the factor substitution and feedback mechanisms. The tax rate decreases with the opportunity cost of leisure time (Bianchi et al., 2001). The decrease of the tax rate stimulates economic development and increases sources of tax revenue.

The optimal corporate tax rate decreases from $34 \%$ in the 1980 s to $26 \%$ in the 2000 s for OECD countries (Brill \& Hassett, 2007). Oliveira and Costa (2013) find that $23 \%$ of the additional tax rate is in the tax penalty area. Accordingly, the income tax preference can reduce the risk of stepping into the tax penalty area and make the tax rate more reasonable (Auerbach et al., 2008). For high-tech enterprises in China, the income tax preference has a similar function. With a tax rate beyond point $\mathrm{H}$, the factor substitution mechanism and feedback mechanism occur similarly. To adjust the tax rate below point $\mathrm{XH}$, such as $\mathrm{X} 1$ corresponding tax revenue at point $A$ has the function of income tax preference and is a way to stimulate R\&D investments (Lévy-Garboua et al., 2009).

Moreover, from the perspective of market failure theory, some externalities make R\&D activities hard to exist independently in the competitive market. Tax incentives exactly offset the externalities of R\&D activities. From the perspective of enterprises' value, the amount of R\&D activities depends on the final cash flow. The after-tax return of R\&D activities $(\eta)$ is utilized to examine whether an enterprise starts an R\&D project (Klassen et al., 2004).

$$
\begin{aligned}
& \eta=\frac{\operatorname{EPV}(\mathrm{CF})\left(1-t_{C F}\right)-\mathrm{RD}\left(1-\mathrm{DR} * t_{D}\right)}{\mathrm{RD}\left(1-\mathrm{DR} * t_{D}\right)}= \\
& =\frac{\operatorname{EPV}(\mathrm{CF})\left(1-t_{C F}\right)}{\mathrm{RD}\left(1-\mathrm{DR} * t_{D}\right)}-1
\end{aligned}
$$

$\mathrm{EPV}(\mathrm{CF})$ is the cash flow from the project; $R D$ is the R\&D expenditure and input; DR 


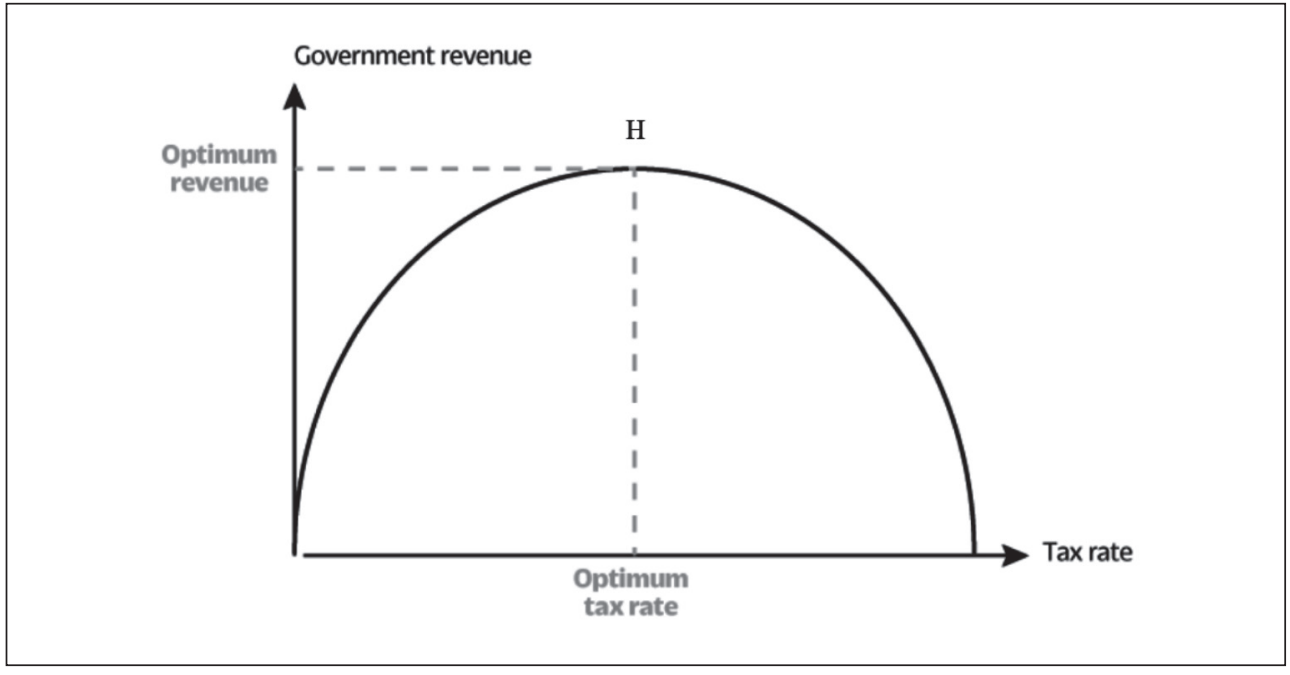

Source: own

is the percentage of pre-tax deduction of research input; $t_{D}$ and $t_{C F}$ are respectively the corporate income tax rate in the term of research input and the term of creating cash inflow; $\mathrm{RD}\left(1-\mathrm{DR} * t_{D}\right)$ is the cost of the R\&D activity; $\operatorname{EPV}(\mathrm{CF})\left(1-t_{C F}\right)-\mathrm{RD}\left(1-\mathrm{DR} * t_{D}\right)$ is the net profit by the research project. Without disturbances, managers only choose projects with a positive after-tax return of R\&D activity. Suppose $\eta$ is zero, the formula is as follows:

$$
\frac{\mathrm{EPV}(\mathrm{CF})}{\mathrm{RD}}=\frac{1-\mathrm{DR} * t_{D}}{1-t_{C F}}
$$

When both $t_{C F}$ and $t_{D}$ are fixed (which also conforms to the reality that the income tax rate is stable with few changes in China), the amount of the enterprises' R\&D input is positively related to the pre-tax deduction proportion of the tax R\&D expenditures. Both $t_{C F}$ and $t_{D}$ (the preferential income tax rate of $15 \%$ for high-tech enterprises is lower than that of $25 \%$ regulatory tax rate in China) decrease with $R \& D$ investments. The additional deduction or income tax rate preferences stimulate enterprises to increase R\&D investments literally. $\mathrm{EPV}(\mathrm{CF})$ is positively associated with $\triangle \mathrm{RD}$. Tax incentives likely increase R\&D investments for high-tech enterprises with high EPV(CF). Accordingly, the first hypothesis of this study is as follows:
H1: There is a positive relationship between income tax preference and R\&D investments of high-tech enterprises.

The government is the primary controlling shareholder of state-owned enterprises, leading state-owned enterprises to play an important role in macro-control and the purpose of making profits. Thus, the tax preference is a kind of government intervention. But, on the other hand, it relies on the 'invisible hand' of market rules to adjust externality and authorize the autonomy for state-owned enterprises to use the preferential income tax. Accordingly, this study proposes the following hypothesis:

H2a: The incentive impact of income tax preference on R\&Dinvestments is more significant for non-state-owned high-tech enterprises than state-owned high-tech enterprises.

The life cycle theory indicates that enterprises generally experience the introduction and growth phases and the mature and decline phases. Enterprises in diverse stages have different characteristics in the operation ability, financing ability, growth ability, and the demand and features of R\&D. High-tech enterprises in different phases have the diversely incentive impact of income tax 
preference on R\&D investments and operational risks from R\&D investments. Enterprises appear to be more susceptible to tax preference in the introduction phase than in the growth and mature stages. In addition, R\&D investments also change distribution characteristics of cash flow. The successful R\&D investment increases the short-term cash outflow and cash inflow in the long term. Enterprises in the decline phase appear to have insignificant R\&D investments as the development life is close to the end. This finding is reflected in the following hypothesis:

$H 2 b$ : The impact of income tax preference on $R \& D$ investments is more significant for enterprises in the introduction phase than those in the growth and mature stages and insignificant in the decline phase.

\section{Research Methodology}

Based on profit-making characteristics and high risk and high return for R\&D investments, enterprises are only willing to have R\&D investments at a moderate level to obtain some potential profits. The incentive of relevant national tax policies reduces the cost and risks of R\&D investments by high-tech enterprises. Accordingly, there is a significantly positive association between income tax preference and R\&D investments of high-tech enterprises. This study examines the relationship between tax incentives and R\&D investments of hightech enterprises by the following model:

$$
\begin{aligned}
& R D I=\beta_{0}+\beta_{1} * E T R_{-} t+\sum_{n=2}^{13} \beta n * \\
& * \text { Control } n+\sum_{m=14}^{16} \beta m^{*} \text { Dummy } m+€
\end{aligned}
$$

\begin{tabular}{|c|c|c|}
\hline Variable name & Symbol & Definition \\
\hline Effective tax rate & ETR_t & (Income tax - deferred income tax)/EBIT \\
\hline R\&D investments & RDI & R\&D expenditure/operating income \\
\hline Ratio of bachelor & Bachelor & $\begin{array}{l}\text { Number of the employee with a bachelor degree or } \\
\text { above/total employees }\end{array}$ \\
\hline Asset-liability ratio & Leverage & Total liabilities/total assets \\
\hline Growth ability & Growth & Income growth rate \\
\hline Government subsidy & GS & $\begin{array}{l}\text { The natural logarithm of the total amount of } \\
\text { government subsidies }\end{array}$ \\
\hline Enterprise size & Size & The natural logarithm of total assets of enterprises \\
\hline Enterprise age & Age & The current year - registered year +1 \\
\hline Standard deviation of sales & SD of sales & $\begin{array}{l}\text { The natural logarithm standard deviation of sales } \\
\text { revenue over the past five years }\end{array}$ \\
\hline Institutional ownership & 10 & $\begin{array}{l}\text { The amount of equity held by institutional investors at } \\
\text { the end of the year/total equity }\end{array}$ \\
\hline Standard deviation of volume & SD of volume & $\begin{array}{l}\text { The natural logarithm of the standard deviation of } \\
\text { average share trading volume over the past three years }\end{array}$ \\
\hline Market to book & MtB & Market value/book value \\
\hline Share price & Price & $\begin{array}{l}\text { The natural logarithm of the share price at the end of } \\
\text { the year }\end{array}$ \\
\hline Standard deviation of returns & SD of returns & $\begin{array}{l}\text { The natural logarithm of the standard deviation of the } \\
\text { average share return over the past three years }\end{array}$ \\
\hline Enterprise property & $\mathrm{BC}$ & 1 if non-state-owned enterprises; 0 otherwise \\
\hline Enterprise location & Location & $\begin{array}{l}\text { One if enterprises located in provinces with high } \\
\text { R\&D investments (Shanghai, Zhejiang, Jiangsu, and } \\
\text { Shandong); } 0 \text { otherwise }\end{array}$ \\
\hline Loss & Loss & One if loss enterprise; 0 otherwise \\
\hline
\end{tabular}

\section{Tab. 1: Variable definitions}


All variable definitions for the formula are provided in Tab. 1.

\subsection{Measurement of Income Tax Preference}

High-tech enterprises in China enjoy a preferential income tax rate of $15 \%$. A nominal tax rate reflects the tax burden of an enterprise. Thus, the tax burden is much different from the nominal tax burden as the current tax credit and preferential tax policies. Previous studies (e.g., Wang \& Wang, 2009; Auerbach \& Poterba, 1987; Balakrishnan et al., 2019) utilize many different measurements for income tax incentives. Following Wang and Wang (2009), this study employs the ETR_t to measure the income tax preference as the income tax deducts the deferred income tax divided by EBIT with three years $(t, t-1, t-2)$.

The income tax is measured on an accrual basis. As the disclosure of deferred income tax, ETR_t is not disturbed by time series compared with cash paying for the income tax. Therefore, ETR_t is a ratio, which can be compared with the statutory income tax of $15 \%$ for high-tech enterprises. In addition, the measure of ETR_t eliminates the impact of the enterprise size and makes samples comparable. As enterprises tend to control income taxes and fees by earnings management, this study follows Balakrishnan et al. (2019) to adjust ETR_t by averaging the previous three years $(t, t-1, t-2)$ to reduce the impact of temporary fluctuations.

Moreover, there is the hysteresis between the dependent and independent variables as the funds on R\&D activities from accumulated retained earnings of the previous year. Consequently, the issue is solved by adjusting ETR_t in time series in this study. As high-tech enterprises enjoy preferential tax policies such as paying a $15 \%$ favorable income tax rate for $R \& D$ investments, the less the ETR_t of hightech enterprises is, the larger the difference between ETR_t and the regulatory income tax rate $15 \%$, the more preferential tax enterprises enjoy.

\subsection{Measurement of R\&D Investments}

The R\&D expenditure is a traditional proxy for enterprises' R\&D investments, including the number of capitals used in R\&D activities for raw materials and labor costs, the purchase of fixed assets, construction costs, management fees, and other expenses. The R\&D expenditure mainly consists of partially administrative expenses, development expenses, and R\&D expenses involved in intangible assets. This study introduces the R\&D intensity (i.e., R\&D expenditure divided by operating income) to measure enterprises' R\&D investments. The larger the R\&D intensity is, the greater the number of R\&D investments an enterprise has.

\subsection{Control Variables}

This study introduces some control variables that may affect the R\&D investments of enterprises. First, enterprises that attach great importance to R\&D investments tend to be knowledge-intensive enterprises with high requirements for $R \& D$ personnel and prefer to hire well-educated employees (Lou \& Xu, 2009). Consequently, this study introduces the proportion of employees with a bachelor's degree or above as a bachelor to control the structure of employees. Second, the tax credit positively influences the increase of R\&D expenditure by enterprises, and the positive impact is more significant for enterprises with a higher asset-liability ratio (Kasahara et al., 2014). Third, enterprises with different capital structures have different reactions to the operational risks of R\&D investments. This study uses the asset-liability ratio as a Leverage to control the demand of enterprises' debt repayment and capital structures.

Furthermore, small-scale enterprises have more flexibility of innovation cooperation while large-scale enterprises can disperse risks by R\&D investments. Accordingly, the size of enterprises has an impact on R\&D investments. This study introduces the natural logarithm of total assets by enterprises as Size to control the effect of enterprise size. In addition to tax incentives, the government also directly provides subsidies to enterprises. This study introduces the natural logarithm of the total government subsidies as GS to control government subsidies' impact on enterprises. Low growth opportunities mitigate the effect of tax credits on increasing R\&D spending (Swenson, 1992). Enterprises in the growth phase are more likely to form core competitiveness by R\&D investments. Accordingly, Growth and Age are used to control the impact of different stages on enterprises.

This study introduces the standard deviation of sales revenue as S.D. of sales, the standard deviation of share trading volume as 
S.D. of volume, and the standard deviation of share returns as S.D. of returns in the formula to control the business fluctuation. In addition, institutional investors tend to make long-term and strategic investments and usually play an important role in corporate governance and $R \& D$ investments. Consequently, this study introduces the shareholding proportion of institutional investors to total equity as $\mathrm{IO}$ in the formula. Moreover, this study introduces the Market-toBook ratio as MtB to control the performance of enterprises in the securities market.

This study also introduces three dummy variables, which are $\mathrm{BC}$ (for state-owned enterprises, $\quad B C=1$; for non-state-owned enterprises, $B C=0$ ), Location (for enterprises located in regions with a lower R\&D level, Location $=1$; for enterprises located in areas with a higher R\&D investment, Location $=0$ ), and Loss (for enterprises with the net Loss in the annual report, Loss $=1$; otherwise, Loss $=0$ ). The non-state-owned enterprises have the greater operationally risk and appear to have more intentions for R\&D investments to pursue the development advantages in the market. Furthermore, the region where enterprises are located can control the geographical complexity in the formula. Therefore, there is a more significant effect of knowledge spillovers for the area with higher R\&D investments. Finally, enterprises with the Loss do not enjoy income tax preferences and appear to reduce R\&D investments. Therefore, the Loss of enterprises affects both income tax preferences and R\&D investments.

\section{Sample}

\subsection{Sample Selection}

This study selects A-share listed high-tech enterprises in China from 2013 to 2018. To ensure the validity of the data, this study screens the data according to standards as follows: (1) select high-tech enterprises with a preferential income tax rate of 15\%; (2) exclude Special Treatment and *Special Treatment enterprises (ST \& *ST enterprises) and enterprises with incomplete information; (3) winsorize variables

Tab. 2:

Descriptive statistics

\begin{tabular}{l|r|r|r|r|r|c}
\multicolumn{1}{c|}{ Variables } & Mean & Std. dev. & P25 & Median & P75 & Ob \\
\hline RDI & 4.843 & 3.551 & 3.030 & 3.960 & 5.610 & 2,975 \\
\hline ETR_t & 0.138 & 0.154 & 0.095 & 0.146 & 0.184 & 2,975 \\
\hline Bachelor & 25.123 & 18.774 & 11.350 & 20.270 & 35.590 & 2,975 \\
\hline Lev & 0.393 & 0.189 & 0.241 & 0.384 & 0.530 & 2,975 \\
\hline Growth & 0.292 & 0.602 & -0.015 & 0.147 & 0.416 & 2,975 \\
\hline GS & 15.077 & 4.305 & 15.067 & 16.113 & 17.032 & 2,975 \\
\hline Size & 22.074 & 1.076 & 21.304 & 21.935 & 22.699 & 2,975 \\
\hline Age & 17.949 & 4.762 & 14.682 & 17.422 & 20.699 & 2,975 \\
\hline S.D. of sales & 19.789 & 1.324 & 18.872 & 19.712 & 20.604 & 2,975 \\
\hline IO & 37.137 & 22.699 & 17.259 & 37.954 & 54.925 & 2,975 \\
\hline S.D. of volume & 6.320 & 0.352 & 6.086 & 6.335 & 6.554 & 2,975 \\
\hline MtB & 3.946 & 2.722 & 2.130 & 3.167 & 4.875 & 2,975 \\
\hline Price & 15.483 & 10.680 & 7.980 & 12.600 & 19.610 & 2,975 \\
\hline S.D. of returns & 12.638 & 4.001 & 9.848 & 11.916 & 14.655 & 2,975 \\
\hline BC & 0.611 & 0.488 & 0.000 & 1.000 & 1.000 & 2,975 \\
\hline Location & 0.299 & 0.458 & 0.000 & 0.000 & 1.000 & 2,975 \\
\hline Loss & 0.087 & 0.281 & 0.000 & 0.000 & 0.000 & 2,975 \\
\hline
\end{tabular}

Note: All variables as previously defined. 
with abnormal values at $\mathbf{1} \%$ and $\mathbf{9 9} \%$ level. The data are extracted from the WIND database and CSMAR database. After filtering, 977 enterprises are included, and this study finally obtained 2,975 samples.

\subsection{Descriptive Statistics}

Tab. 2 presents the descriptive statistics. The sample enterprises in this study are comprised of fairly large, mature, and most profitable. The samples in this study have an average age of 17.949 years. The average value of ETR_t is $13.8 \%$, lower than the statutory income tax rate of $15 \%$ for high-tech enterprises, which can be attributed to tax aggressiveness and tax credit such as the additional deduction, tax planning, and overseas business. The standard deviation of ETR_t is relatively high at 0.154 , and $\mathrm{P} 25$ and $\mathrm{P} 7 \overline{5}$ are respectively 0.095 and 0.184 , indicating a significant cross-sectional difference of income tax preference among high-tech enterprises.

\subsection{Pearson Correlations}

The untabulated results show that the Pearson correlation matrix for the main variables. There is an insignificant correlation between ETR_t and RDI. However, the bachelor is significantly and positively related to RDI. Enterprises attaching great importance to R\&D activities require a higher educational level of employees. There is also a positive correlation between Growth and RDI. Enterprises with more emphasis on $R \& D$ activities have greater growth potential.

\section{Research Results}

\subsection{The Relation between ETR_t and RDI}

This study establishes a linear regression model by using ETR_t to measure income tax preference and RDI to measure the R\&D investments of enterprises. Tab. 3 shows the regression results. Time effect and industry effect are included. The F-value is 72.961 with a significant level of $1 \%$, indicating a substantial relation between independent and dependent variables. The adjusted $R$-squared is 0.279 , meaning that the independent variables can better explain the R\&D investments of hightech enterprises. VIF values of all variables are less than 10 . There is no multicollinearity problem in the regression model. ETR_t of enterprises is negatively related to the RDI at a significant level of $1 \%$. RDI of high-tech enterprises increases by 1.873 units on average when ETR_t decreases by 1 unit. Income tax incentives effectively promote high-tech enterprises to increase R\&D investments. The results are consistent with De Waegenaere et al. (2012). The income tax preference increases with R\&D investments of enterprises. High-tech enterprises with income tax incentives have more cash flow to conduct R\&D activities. The income tax expense directly leads to the cash outflow of high-tech enterprises and is a high cost for high-tech enterprises to develop R\&D activities (Zhao, 2019). However, income tax incentives reduce the tax expenses of enterprises and increase the after-tax profits of high-tech enterprises, leading them to have more capital for innovations.

In addition, the income tax preference can reduce risks of enterprises, including financial risks and operational risks. The former mainly comes from the pressure to control the continuity and stability of the capital chain in case enterprises get into a debt crisis or out of capital. The income tax preference reduces the cash outflow of enterprises, which can reduce the demand for financing activities of enterprises, thus reducing financial risks. The operational risk primarily results from the bankruptcy risk. Therefore, the need for funds reduces the operational risk. High-tech enterprises have a significant capability for the reduction of R\&D risks. Preferential income tax policies support high-tech enterprises for R\&D activities. Consequently, income tax incentives have a positive effect on the R\&D investments of high-tech enterprises.

Moreover, there is a positive relation between Bachelor and RDI at the significant level of $1 \%$. The results seem to suggest that enterprises need knowledge-intensive operating activities and R\&D innovations. Leverage is significantly and negatively associated with $\mathrm{RDI}$ at a $1 \%$ level, possibly due to the cash flow generated by high financial leverage, which can be put into R\&D investments. A high assetliability ratio shows the radical operation style of enterprises more willing to carry out high-risk $R \& D$ investments. There is insignificant relation between Growth and RDI, likely due to the high risk of R\&D investments. Enterprises with successful R\&D activities gain profits and grow fast. However, the unsuccessful R\&D activities bring considerable losses to enterprises. 
Tab. 3: Regression results of RDI on income tax preference

\begin{tabular}{|c|c|c|c|c|c|}
\hline & B & T-value & P-value & Sig & VIF \\
\hline$\beta_{0}$ & 9.124 & 6.185 & 0.000 & *** & \\
\hline ETR_t & -1.873 & -5.133 & 0.000 & *** & 1.044 \\
\hline Bachelor & 0.070 & 22.948 & 0.000 & *** & 1.184 \\
\hline Lev & -3.439 & -9.117 & 0.000 & *** & 1.966 \\
\hline Growth & -0.110 & -1.006 & 0.314 & & 1.159 \\
\hline GS & 0.029 & 2.437 & 0.015 & ** & 1.075 \\
\hline Size & 0.347 & 3.030 & 0.002 & *** & 6.120 \\
\hline Age & -0.017 & -1.481 & 0.139 & & 1.112 \\
\hline S.D. of sales & -0.487 & -7.449 & 0.000 & *** & 2.987 \\
\hline 10 & -0.014 & -5.317 & 0.000 & *** & 1.359 \\
\hline S.D. of volume & -0.508 & -1.980 & 0.048 & $* *$ & 2.642 \\
\hline MtB & 0.025 & 0.780 & 0.436 & & 2.393 \\
\hline Price & 0.004 & 0.523 & 0.601 & & 2.404 \\
\hline S.D. of returns & 0.073 & 4.051 & 0.000 & $* * *$ & 1.637 \\
\hline$B C$ & 0.249 & -1.953 & 0.051 & * & 1.528 \\
\hline Location & -0.456 & -3.810 & 0.000 & $* * *$ & 1.127 \\
\hline Loss & 1.097 & 5.271 & 0.000 & *** & 1.120 \\
\hline Year \& Ind & Yes & & & & \\
\hline Adjusted $\mathrm{R}^{2}$ & 0.279 & & & & \\
\hline $\mathrm{F}$ & 72.961 & & 0.000 & $* * *$ & \\
\hline
\end{tabular}

Note: All variables as previously defined. ${ }^{* * *},{ }^{* *}$ and ${ }^{*}$ denote significance at the 1,5 , and $10 \%$ levels, respectively.

Government Subsidies (GS) are positively related to RDI at the significant level of $5 \%$. However, the value for the coefficient is only 0.29 , which is lower than ETR_t, indicating that government subsidies can also stimulate the innovation of high-tech enterprises. The effect is not as effective as the tax relief. Size is also significantly and positively related to RDI at $1 \%$, indicating a scale effect on R\&D investments. Interestingly, there is insignificant relation between Age and RDI. The listing years of enterprises have no impact on R\&D investments. Importantly, this study finds that the proportion of institutional investors $(\mathrm{IO})$ is negatively related to $\mathrm{RDI}$ at the significant level of $1 \%$. The findings seem to suggest that strategic investors tend to focus on the long-term development of enterprises. Institutional investors appear to have a relatively pessimistic attitude towards the return risks of R\&D investments, reflecting that the power of capital exerts restrictions on the development of high-tech enterprises in China. The share price is affected by the market information and determined by the supply-demand relation in the market. There is insignificant relation between Price and RDI. Finally, the market-to-book (MtB) of enterprises is insignificantly related to RDI.

\subsection{State-owned Enterprises and Non-state-owned Enterprises}

State-owned enterprises are performed by the state council and the local government. Tab. 4 shows the regression results. The F-value is 70.139 , significant at the $1 \%$ level, indicating a substantial relation between independent and 
Tab. 4: Regression results of RDI on income tax preferences with variable $\mathbf{Z}$

\begin{tabular}{|c|c|c|c|c|c|}
\hline & B & T-value & P-value & Sig & VIF \\
\hline$\beta_{0}$ & 9.103 & 6.188 & 0.000 & *** & \\
\hline ETR_t & -0.424 & -0.853 & 0.000 & *** & 1.954 \\
\hline Bachelor & 0.070 & 23.058 & 0.000 & *** & 1.185 \\
\hline Lev & -3.487 & -9.268 & 0.000 & $* * *$ & 1.968 \\
\hline Growth & -0.129 & -1.186 & 0.236 & & 1.161 \\
\hline GS & 0.029 & 2.448 & 0.014 & ** & 1.075 \\
\hline Size & 0.352 & 3.081 & 0.002 & ** & 6.121 \\
\hline Age & -0.017 & -1.531 & 0.126 & & 1.112 \\
\hline S.D. of sales & -0.490 & -7.522 & 0.000 & *** & 2.988 \\
\hline 10 & -0.014 & -5.346 & 0.000 & *** & 1.359 \\
\hline S.D. of volume & -0.541 & -2.113 & 0.035 & ** & 2.645 \\
\hline MtB & 0.028 & 0.879 & 0.379 & & 2.394 \\
\hline Price & 0.004 & 0.496 & 0.620 & & 2.404 \\
\hline S.D. of returns & 0.075 & 4.144 & 0.000 & $* * *$ & 1.638 \\
\hline $\mathrm{BC}$ & 0.678 & 4.184 & 0.000 & $* * *$ & 2.486 \\
\hline Location & -0.441 & -3.693 & 0.000 & *** & 1.128 \\
\hline Loss & 1.140 & 5.483 & 0.000 & $* * *$ & 1.122 \\
\hline Z & -3.064 & -4.266 & 0.000 & *** & 3.081 \\
\hline Year \& Ind & Yes & & & & \\
\hline Adjusted $\mathrm{R}^{2}$ & 0.283 & & & & \\
\hline $\mathrm{F}$ & 70.139 & & 0.000 & $* * *$ & \\
\hline
\end{tabular}

Source: own

Note: All variables as previously defined. ${ }^{* * *},{ }^{* *}$ and ${ }^{*}$ denote significance at the 1,5 , and $10 \%$ levels, respectively.

dependent variables. The adjusted R-squared is 0.283 , meaning that independent variables well explain the R\&D investments of high-tech enterprises. VIF values of all variables are less than 10 . Thus, there is no multicollinearity problem in the regression model.

ETR_t is significantly and negatively associated with RDI at the level of $1 \%$. The interaction term $\mathrm{Z}$ is negatively associated with RDI at a significant level of $1 \%$. The coefficient of interaction term $\mathrm{Z}$ is -2.64 . Non-SOEs are more sensitive to income tax preferences than SOEs, consistent with Liu (2017) and Zhu (2019). Income tax incentives of R\&D investments are more effective for non-SOEs than SOEs. Some SOEs hold an oligopoly in China and are unlikely to follow the 'invisible hand' mechanism or even against macro-control functions. SOEs are supported by government funds and have less pressure to operate in an advantage status. In addition, agent problems lead SOEs than non-SOEs to have relatively insufficient awareness of innovations for income tax incentives (Zhu et al., 2019). R\&D investments play an important role in the overall innovation and development of countries. SOEs have to pay more attention to income tax preferences, improve R\&D investments, and increase diverse equity ownership (Zhu et al., 2019). Non-SOEs without political burdens can more effectively strengthen corporate management and enhance the motivation of earning profits. 


\subsection{Robustness Verification}

The life cycle phase is related to enterprise risk preference and performance (Shahzad et al., 2019). High-tech enterprises in different life phases have diverse incentive effects of income tax preferences and responses to additional risks of R\&D investments. Based on the interest of shareholders, Erosa and Gonzalez (2019) divide the life cycle into the phases of share issuance, growth, and dividend distribution. However, this study adopts the classic theory by Adizes (1979), who divides the life cycle into 4 phases: the introduction and growth phases, the mature and decline phases. Enterprises in different stages have distinctive financial leverage and financial ratios (Castro et al., 2019). The features of life cycle phases result from enterprise performance and resource allocation. Cash flow is a measure to reflect enterprise performance in different life cycle phases. This study follows the methodology by Dickinson (2011) to divide the life cycle phases of the enterprise.

\begin{tabular}{l|l}
$\begin{array}{c}\text { Life cycle } \\
\text { phases }\end{array}$ & \multicolumn{1}{c}{ Pattern } \\
\hline Introduction & CFFO $<0$, CFFIN $<0$ and CFFF $>0$ \\
\hline Growth & CFFO $>0$, CFFIN $<0$, and CFFF $>0$ \\
\hline Mature & CFFO $>0$, CFFIN $<0$, and CFFF $<0$ \\
\hline Decline & $\begin{array}{l}\text { CFFO }<0, \text { CFFIN }>0, \text { and CFFF } \leq \\
\text { or } \geq 0\end{array}$ \\
\hline
\end{tabular}

CFFO, CFFIN, and CFFF respectively indicate the cash flow of enterprises from operating activities, investment activities, and financing activities. This study selects listed high-tech enterprises in China from 2013 to
2018. 940 high-tech enterprises remain. 122, 534, 274, and 10 sample enterprises are classified into the introduction, growth, mature, and decline phases.

Tab. 5 reports subgroup regression results. In the introduction phase, there is a significantly negative relation between ETR_t and RDI. The absolute value of the coefficient is almost twice that in the mature stage. The major capital sources of start-up enterprises come from financing activities. The enterprises purchase fixed assets to form a competitive advantage. The demand for R\&D activities to set up the core competitiveness of enterprises is relatively important. Consequently, the income tax preference effectively stimulates R\&D investments in the introduction phase.

ETR_t of high-tech enterprises in growth and mature phases are most significantly and negatively related to RDI. The reason is that high-tech enterprises are gradually stable and can bear risks. Therefore, high-tech enterprises are willing to take advantage of tax incentives to reduce unnecessary cash flow from R\&D activities. In addition, the coefficient in the growth phase is slightly larger than that in the mature stage, indicating that enterprises in the growth phase have a greater demand for R\&D investments to improve competitiveness. Therefore, high-tech enterprises in such a phase tend to be more sensitive to tax incentives.

Enterprises in the decline phase have insignificant demand for R\&D investments. The coefficient for ETR_t is -7.425 . Innovation input is a key factor for the development of high-tech enterprises. However, income tax preference becomes less positively related with R\&D investments from the introduction, growth,

\section{Tab. 5: Subgroup regression results}

\begin{tabular}{l|c|c|c|c|c|c} 
& B & P-value & Sig & Adjusted $\mathbf{R}^{2}$ & F_Sig & Year \& Ind \\
\hline Introduction & -3.257 & 0.054 & $*$ & 0.332 & 0.000 & Yes \\
\hline Growth & -1.999 & 0.001 & ${ }^{* * *}$ & 0.260 & 0.000 & Yes \\
\hline Mature & -1.668 & 0.000 & ${ }^{* * *}$ & 0.282 & 0.000 & Yes \\
\hline Decline & -7.425 & 0.332 & & 0.877 & 0.001 & Yes \\
\hline Others & 0.993 & 0.495 & & 0.603 & 0.000 & Yes \\
\hline
\end{tabular}


and mature phases. Accordingly, high-tech enterprises stepping into the mature phase still have to maintain R\&D investments to maintain market competitiveness.

\section{Sensitivity Analyses}

\subsection{Alternative Proxy for R\&D Investments}

This study utilizes R\&D staff which is calculated as the percentage of research staff in hightech enterprises as an alternative proxy of R\&D investments. Tab. 6 shows the regression results. The F-value of the overall regression formula is 167.797, which is significant at the $1 \%$ level, indicating a substantial relation between independent and dependent variables. The adjusted R-squared is 0.452 , meaning that explanatory variables well explain the R\&D investments of high-tech enterprises. VIF values are less than 10 , suggesting that there is no multicollinearity problem in the regression model. There is an insignificantly positive association between ETR_t and R\&D staff.

In addition, there is a significantly positive relation between Bachelor and R\&D staff, supporting the duality of R\&D staff and highly educated staff. The growth of enterprises is significantly and positively associated with R\&D staff, indicating that high-tech enterprises with rapid growth appear to have a better prospect and cope with more risks by R\&D investments. Consequently, enterprises in high-speed growth have a high demand for research staff for R\&D activities.

\section{Tab. 6: Regressions of R\&D staff on income tax preference}

\begin{tabular}{|c|c|c|c|c|c|}
\hline & B & T-value & P-value & Sig & VIF \\
\hline$\beta_{0}$ & 27.483 & 4.909 & 0.000 & $* * *$ & \\
\hline ETR_t & 0.070 & 0.051 & 0.959 & & 1.047 \\
\hline Bachelor & 0.533 & 45.647 & 0.000 & $* * *$ & 1.185 \\
\hline Lev & -1.943 & -1.363 & 0.173 & & 1.961 \\
\hline Growth & 2.124 & 5.150 & 0.000 & $* * *$ & 1.159 \\
\hline GS & 0.117 & 2.485 & 0.013 & $* *$ & 1.075 \\
\hline Size & -1.535 & -3.551 & 0.000 & $* * *$ & 5.978 \\
\hline Age & -0.068 & -1.583 & 0.114 & & 1.116 \\
\hline S.D. of sales & 0.184 & 0.748 & 0.455 & & 2.941 \\
\hline 10 & -0.023 & -2.315 & 0.021 & ** & 1.355 \\
\hline S.D. of volume & 1.733 & 1.806 & 0.071 & * & 2.600 \\
\hline $\mathrm{MtB}$ & -0.166 & -1.399 & 0.162 & & 2.380 \\
\hline Price & -0.062 & -2.065 & 0.039 & ** & 2.387 \\
\hline S.D. of returns & 0.191 & 2.738 & 0.006 & $* * *$ & 1.618 \\
\hline$B C$ & -0.302 & -0.627 & 0.531 & & 1.510 \\
\hline Location & 1.681 & 3.724 & 0.000 & *** & 1.116 \\
\hline Loss & -2.264 & -2.872 & 0.004 & $* * *$ & 1.129 \\
\hline Year \& Ind & Yes & & & & \\
\hline Adjusted $\mathrm{R}^{2}$ & 0.452 & & & & \\
\hline $\mathrm{F}$ & 167.797 & & 0.000 & $* * *$ & \\
\hline
\end{tabular}




\subsection{Alternative Proxy for Income Tax Preference}

This study employs BTD_t as the alternative proxy for ETR_t. BTD_t is calculated as the total profit less the ratio of actual income tax to applicable income tax over three years. Tab. 7 shows the regression results. The F-value of the overall regression formula is 70.759 , which is significant at the $1 \%$ level, indicating a substantial relation between independent and dependent variables. The adjusted R-squared is 0.273 , meaning that explanatory variables well explain the R\&D investments of high-tech enterprises. VIF values are less than ten, indicating that there is no multicollinearity problem in this regression model.

BTD_t measure from the perspective of booktax difference is not affected by the $15 \%$ income tax rate. Thus, there is an insignificantly positive relation between BTD_t and RDI. Furthermore, the findings suggest an insignificant impact of other tax incentives such as additional deduction and the preferential income tax rate on R\&D investments of high-tech enterprises.

\subsection{Loss Enterprises}

Loss enterprises do not need to pay for income tax and have no income tax preference. R\&D investments increase corporate expenditure and reduce profits. High-tech enterprises with relatively higher R\&D investments likely face greater loss risk, at least in the short term. Tab. 8 reports the regression results. The coefficient of ETR_t is -1.668 at the significant level of $1 \%$, indicating that income tax incentives stimulate innovation of high-tech enterprises. The results are robust.

\section{Tab. 7: Regression results of RDI on BTD_t}

\begin{tabular}{|c|c|c|c|c|c|}
\hline & B & T-value & P-value & Sig & VIF \\
\hline$\beta_{0}$ & 8.611 & 5.821 & 0.000 & *** & \\
\hline BTD_t & 0.001 & 0.924 & 0.355 & & 1.043 \\
\hline Bachelor & 0.069 & 22.498 & 0.000 & $* \star *$ & 1.179 \\
\hline Lev & -3.287 & -8.698 & 0.000 & $* * *$ & 1.956 \\
\hline Growth & -0.102 & -0.934 & 0.350 & & 1.160 \\
\hline GS & 0.029 & 2.383 & 0.017 & $* *$ & 1.076 \\
\hline Size & 0.349 & 3.029 & 0.002 & $* \star *$ & 6.134 \\
\hline Age & -0.018 & -1.618 & 0.106 & & 1.122 \\
\hline S.D. of sales & -0.489 & -7.451 & 0.000 & $* * *$ & 2.988 \\
\hline 10 & -0.013 & -5.183 & 0.000 & $* * *$ & 1.358 \\
\hline S.D. of volume & -0.468 & -1.818 & 0.069 & * & 2.640 \\
\hline MtB & 0.031 & 0.989 & 0.323 & & 2.400 \\
\hline Price & 0.003 & 0.321 & 0.748 & & 2.414 \\
\hline S.D. of returns & 0.073 & 3.989 & 0.000 & *** & 1.639 \\
\hline$B C$ & 0.240 & 1.876 & 0.061 & * & 1.530 \\
\hline Location & -0.465 & -3.874 & 0.000 & *** & 1.126 \\
\hline Loss & 1.228 & 5.876 & 0.000 & $* * *$ & 1.118 \\
\hline Year \& Ind & Yes & & & & \\
\hline Adjusted $\mathrm{R}^{2}$ & 0.273 & & & & \\
\hline $\mathrm{F}$ & 70.759 & & 0.000 & $* * *$ & \\
\hline
\end{tabular}




\section{Tab. 8: Regression results of RDI on income tax preference with Loss $=0$}

\begin{tabular}{|c|c|c|c|c|c|}
\hline & B & T-value & $\mathrm{P}$-value & Sig & VIF \\
\hline$\beta_{0}$ & 8.837 & 6.051 & 0.000 & $* * *$ & \\
\hline ETR_t & -1.668 & -4.314 & 0.000 & $* * *$ & 1.035 \\
\hline Bachelor & 0.066 & 21.713 & 0.000 & $* * *$ & 1.201 \\
\hline Lev & -3.265 & -8.758 & 0.000 & $* * *$ & 1.873 \\
\hline Growth & -0.069 & -0.647 & 0.518 & & 1.163 \\
\hline GS & 0.029 & 2.425 & 0.015 & $* *$ & 1.072 \\
\hline Size & 0.406 & 3.549 & 0.000 & $* * *$ & 6.235 \\
\hline Age & -0.011 & -0.983 & 0.326 & & 1.111 \\
\hline S.D. of sales & -0.488 & -7.529 & 0.000 & $* * *$ & 3.016 \\
\hline 10 & -0.015 & -5.694 & 0.000 & $* \star * *$ & 1.350 \\
\hline S.D. of volume & -0.708 & -2.792 & 0.005 & $* * *$ & 2.662 \\
\hline MtB & 0.061 & 1.888 & 0.059 & * & 2.482 \\
\hline Price & 0.001 & 0.156 & 0.876 & & 2.459 \\
\hline S.D. of returns & 0.089 & 4.917 & 0.000 & $* * *$ & 1.644 \\
\hline $\mathrm{BC}$ & 0.116 & 0.928 & 0.354 & & 1.502 \\
\hline Location & -0.385 & -3.306 & 0.001 & $* * *$ & 1.119 \\
\hline Year \& Ind & Yes & & & & \\
\hline Adjusted $\mathrm{R}^{2}$ & 0.283 & & & & \\
\hline $\mathrm{F}$ & 73.440 & & 0.000 & $* * *$ & \\
\hline
\end{tabular}

Note: All variables as previously defined. ${ }^{* * *},{ }^{* *}$ and ${ }^{*}$ denote significance at the 1,5 , and $10 \%$ levels, respectively.

\subsection{Regions of Enterprises}

Geographic complexity likely affects enterprise operation. Although many enterprises operate trans-regionally or transnationally and have multiple operation points, their R\&D activities are often concentrated in the headquarters. A lot of different types of partners are involved in the innovation process. Each offers significant resources (Ritter \& Gemünden, 2004). While attaching importance to independent research to highly rely on the market, enterprises also realize the importance of collaborative innovations in the same industry or related industry. How enterprises gain more 'research bonus' from other enterprises is closely related to the geographical Location or regional environment. The concentration of human capital in cities brings extra productivity
(Rauch, 1991). The clustering and proximity of enterprises in geographical locations promote the knowledge spillover effect, which plays an important role in enterprise innovation (Bottazzi \& Peri, 2002; Bathelt et al., 2004). In addition, regions with higher innovation levels also provide better infrastructure and atmosphere for enterprises to innovate and transform innovation achievement into products. The incentive of income tax preference is affected by the Location of enterprises. Accordingly, this study introduces the dummy variable of Location.

The untabulated results show that the VIF in the model is less than 10, indicating no multicollinearity problem for all variables. The coefficient of ETR_t is -1.632 and is significantly and negatively related to RDI, showing that 
income tax preference significantly affects regions with low $R \& D$ investments. The findings seem to suggest that some locations are less competitive for research. Accordingly, the better use of geographical advantages to improve knowledge acquisition and independent innovation is an important issue faced by hightech enterprises.

Enterprises are likely influenced by other factors from the external environment (Balakrishnan et al., 2019). This study classifies the influence of regions on R\&D investments into market factors, and government factors based on the public power interfere. On the other hand, knowledge spillover effects, innovative atmosphere, and supportive infrastructure are caused by geographical Location or resources among regions without government interference. For instance, there is an advantage of economic development in the eastern areas of China. There appear to be better research facilities in these places.

However, local governments can make up the resource of regions through policies. Local economic development promoted by local governments is significantly and positively related to enterprises' R\&D investments (Fu \& Wei, 2019). Local governments can also provide enterprises with tax incentives and refunds for economic development. But, tax incentives reduce the source of funds for local governments. To raise funds to meet the needs of administrative expenditure, local governments likely issue more government bonds or use other means for financing, thus aggravating the explicit debt of the government and thereby increasing the debt ratio. Such a ratio reflects a lot of factors about locations.

An interesting issue is whether omitted factors rather than knowledge spillover effect between regions affect the relation between income tax preference and enterprises' R\&D investments. This study introduces the dummy variable of Location2 as a substitute for variable Location. One if enterprises in regions where the debt ratio is over $30 \%$; 0 otherwise. Then, an interaction term Z2 (Z2 = ETR_t * Location2) is introduced into the model for robustness analysis.

The untabulated results show that the income tax preference is significantly and negatively related to R\&D investments of hightech enterprises. However, the interaction term $\mathrm{Z2}$ is insignificant. The findings suggest that locations by debt ratios of local governments have an insignificant impact on income tax incentives.

\section{Conclusions}

Tax preferential policies to support the development of enterprises and improve the national competitiveness of technology are generally adopted by most countries worldwide. For example, in China, the government mainly adopts preferential tax policies by applying a $15 \%$ preferential income tax rate for high-tech enterprises and additional deduction in taxable income.

This study aims to explore the relationship between income tax preference and R\&D investments of high-tech enterprises. This study selects listed high-tech enterprises in China from 2013 to 2018 as samples. The empirical results show that the effective income tax rate among high-tech enterprises in China differs widely. The findings suggest that high-tech enterprises in China have to take advantage of preferential income tax, pay more attention to R\&D investments, and strive to improve R\&D ability and market competitiveness. In addition, there is a significantly positive relationship between income tax preference and R\&D investments of high-tech enterprises, indicating that the preferential tax rate policy and other tax incentives such as additional tax deduction increase R\&D investments of hightech enterprises effectively.

Furthermore, the positive relationship between income tax preference and R\&D investments of high-tech enterprises is more significant for non-SOEs. Non-SOEs have stronger governance efficiency. Therefore, SOEs should make better use of income tax preference and improve innovation enthusiasm. Moreover, this study finds a more positive relationship between income tax preference and R\&D investments among high-tech enterprises in the introduction phase than in the growth and mature phases. However, the relation between income tax preference and R\&D investments is insignificant for high-tech enterprises in the decline phase. The findings seem to provide a new perspective for the life cycle characteristics of enterprises and the theoretical guidance to enterprises in phases of growth, mature and decline to develop R\&D investments better. Finally, loss enterprises or enterprises in geographical units with the 
innovative environment are eliminated in this study to avoid extra interference. The results remain robust, indicating that preferential income tax policies applied in high-tech enterprises are significantly and positively associated with R\&D investments.

In conclusion, this study contributes to the literature discussing the economic consequences of the income tax preference from a new perspective, namely, from the perspective of the impact of the preferential income tax on the R\&D investment of high-tech enterprises.

The findings of this study are of value and importance. First, by categorizing the sample enterprises into SOEs and nonSOEs, the results provide the implications for the corporate managers attempting to enhance the development by the income tax preference without the substantial R\&D investment. Second, this study concentrates on high-tech enterprises in China as the extant literature is mainly based on the developed countries. However, the enterprises' innovation performance is very different between developed and developing countries (Raffo et al., 2008). Thus, the findings of this study have implications for developing countries to understand better the impact of preferential income tax on the R\&D investment of hightech enterprises. Finally, this study compares the different incentive effects of income tax preference on high-tech enterprises in different life cycle phases and finds that enterprises in the introduction phase have a more significantly positive relation between income tax preference and R\&D investment than enterprises in the growth phase and mature phase (Koberg et al., 1996). The findings provide enterprises in different life cycle phases with valuable suggestions to develop their R\&D ability.

Enterprises should utilize income tax incentives that are positively related to R\&D activities as much as possible. The certification of high-tech enterprises in China is reformed and stricter in 2020. Therefore, the R\&D input is emphasized, but the R\&D output is also very important as $30 \%$ of certification content is the ability of technology transformation. With the certification improvement, governments should fully play a role in guiding enterprises to $R \& D$ investments.

\section{References}

Adizes, I. (1979). Organizational passages - Diagnosing and treating lifecycle problems of organizations. Organizational Dynamics, 8(1), 3-25. https://doi.org/10.1016/00902616(79)90001-9

Auerbach, A. J., Devereux, M. P., \& Simpson, H. (2008). Taxing Corporate Income (NBER Working Paper No. w14494). Cambridge, MA: National Bureau of Economic Research. https://doi.org/10.3386/w14494

Auerbach, A. J., \& Poterba, J. M. (1987). Tax Loss Carryforwards and Corporate Tax Incentives (NBER Working Paper No. 1863). Cambridge, MA: National Bureau of Economic Research. https://doi.org/10.3386/w1863

Balakrishnan, K., Blouin, J. L., \& Guay, W. R. (2019). Tax Aggressiveness and Corporate Transparency. Accounting Review, 94(1), 45-69. https://doi.org/10.2308/accr-52130

Bathelt, H., Malmberg, A., \& Maskell, P. (2004). Clusters and knowledge: local buzz, global pipelines, and the process of knowledge creation. Progress in Human Geography, 28(1), 31-56. https://doi.org/10.1191/0309132504ph469oa

Bianchi, M., Gudmundsson, B. R., \& Zoega, G. (2001). Iceland's Natural Experiment in Supply-Side Economics. American Economic Review, 91(5), 1564-1579. https://doi. org/10.1257/aer.91.5.1564

Bottazzi, L., \& Peri, G. (2002). Innovation and Spillovers in Regions: Evidence from European Patent Data. European Economic Review, 47(4), 687-710. https://doi.org/10.1016/s00142921(02)00307-0

Brill, A., \& Hassett, K. A. (2007). RevenueMaximizing Corporate Income Taxes: The Laffer Curve in OECD Countries (AEI Working Paper \#137). Washington, DC: American Enterprise Institute.

Bronzini, R., \& Piselli, P. (2016). The impact of R\&D subsidies on firm innovation. Research Policy, 45(2), 442-457. https://doi. org/10.1016/j.respol.2015.10.008

Cao, J. L. (2009). Significance of the Recognition of High-tech Enterprises in the New Era. Science \& Technology Industry of China, (02), 10-12.

Cappelen, Å., Raknerud, A., \& Rybalka, M. (2012). The effects of R\&D tax credits on patenting and innovations. Research Policy, 41(2), 334345. https://doi.org/10.1016/j.respol.2011.10.001

Castro, P., Tascón Fernández, M. T., Amor-Tapia, B., \& de Miguel, A. (2016). Target 
leverage and speed of adjustment along the life cycle of European listed firms. Business Research Quarterly, 19(3), 188-205. https:// doi.org/10.1016/j.brq.2016.01.003

Chen, M. G., \& Fang, C. C. (2012). Research on Incentive Effect of Income Tax Preferential Policy on High and New Technology Industry. Economy and Management, 26(11), 71-76.

Koberg, C. S., Uhlenbruck, N. L., \& Sarason, Y. (1996). Facilitators of organizational innovation: The role of lifecycle stage. Journal of Business Venturing, 11(2), 133-149. https:// doi.org/10.1016/0883-9026(95)00107-7

Crespi, G., Giuliodori, D., Giuliodori, R., \& Rodriguez, A. (2016). The effectiveness of tax incentives for R\&D+i in developing countries: The case of Argentina. Research Policy, 45(10), 2023-2035. https://doi.org/10.1016/j. respol.2016.07.006

Czarnitzki, D., Hanel, P., \& Rosa, J. M. (2011). Evaluating the impact of R\&D tax credits on innovation: A microeconometric study on Canadian firms. Research Policy, 40(2), 217229. https://doi.org/10.1016/j.respol.2010.09.017

De Waegenaere, A., Sansing, R. C., \& Wielhouwer, J. C. (2012). Multinational Taxation and R\&D Investments. The Accounting Review, 87(4), 1197-1217. https://doi.org/10.2308/accr10281

Dickinson, V. (2011). Cash Flow Patterns as a Proxy for Firm Life Cycle. Accounting Review, 86(6), 1964-1994. https://doi.org/10.2308/accr10130

Elschner, C., Ernst, C., Licht, G., \& Spengel, C. (2011). What the design of an R\&D tax incentive tells about its effectiveness: A simulation of R\&D tax incentives in the European Union. The Journal of Technology Transfer, 36, 233-256. https://doi.org/10.1007/ s10961-009-9146-y

Erosa, A., \& González, B. (2019). Taxation and the life cycle of firms. Journal of Monetary Economics, 105, 114-130. https://doi. org/10.1016/j.jmoneco.2019.04.006

Fu, G. J., \& Wei, W. (2019). The Influence of Initiative to Develop Economy of Prefecturelevel City Governments on Enterprise R\&D Input. China Journal of Commerce, (20), 209212.

Gokhberg, L., Kitova, G., \& Roud, V. (2014). Tax Incentives for R\&D and Innovation: Demand versus Effects. Foresight - Russia, 8(3), 18-41. https://doi.org/10.17323/1995459x.2014.3.18.41
Gu, X. L., \& Wang, P. (2017). The influence of government subsidies and tax incentives on the technological innovation of high-tech enterprises. Western Finance and Accounting, (08), 13-16.

Hall, B. H. (1993). R\&D Tax Policy During the 1980s: Success or Failure. Tax Policy and the Economy, 7, 1-35. https://doi.org/10.1086/ tpe.7.20060628

Kasahara, H., Shimotsu, K., \& Suzuki, M. (2014). Does an R\&D tax credit affect R\&D expenditure? The Japanese R\&D tax credit reform in 2003. Journal of the Japanese \& International Economics, 31, 72-97. https://doi. org/10.1016/j.jjie.2013.10.005

Kamien, M. L., \& Schwartz, N. L. (1975). Market structure and innovation: A survey. Journal of Economic Literature, 13, 1-37.

Klassen, K. J., Pittman, J. A., \& Reed, M. P. (2004). A Cross-national Comparison of R\&D Expenditure Decisions: Tax Incentives and Financial Constraints. Contemporary Accounting Research, 21(3), 639-680. https:// doi.org/10.1506/cf2e-huvc-gafy-5h56

Laffer, A. B. (2004). The Laffer Curve: Past, Present, and Future (Report No. 1765). Washington, DC: Heritage Foundation. https:// doi.org/10.2139/ssrn.2182070

Lévy-Garboua, L., Masclet, D., \& Montmarquette, C. (2009). A Behavioral Laffer Curve: Emergence of a Social Norm of Fairness in a Real Effort Experiment. Journal of Economic Psychology, 30(2), 147-161. https:// doi.org/10.1016/j.joep.2008.09.002

Liao, T. T., \& Xiao, J. S. (2018). The incentive effect of income tax preferential policies on R\&D investment - Based on the empirical evidence of listed high-tech enterprises in Fujian. Journal of Fujian Agriculture and Forestry University, 21(06), 49-54.

Liu, X. M. (2017). The Effect of Enterprise Income Tax Preferences on R\&D of Hi-tech Companies: An Analysis of Fujian's Listed Hitech Companies. Science and Technology Management Research, 37(21), 29-34.

Li, X. J., Yuan, C. L., \& Wu, J. G. (2015). Research on the Incentive Effect of Tax Preferential Policies on Independent Innovation of Enterprises in China-Based on GMM Analysis of R\&D Investment Intensity of 274 Enterprises on GEM Board of Shenzhen Stock Exchange. China Collective Economy, (21), 74-79.

Lou, H. T., \& Xu, H. P. (2009). Private Technology Innovation Motivated by 
Government: Empirical Study on Stimulation Effect of Tax Credit. China Accounting Review, 7(02), 191-206.

Lu, J. S., Zhang, S. M., \& Zhu, Y. Y. (2008). Can the High \& New-Tech Enterprise Identification Reduce Financing Constraints? Finance Forum, 23(01), 52-65.

Meng, Q. Q. (2003). American hightech industry tax preferential policy and its enlightenment to China. Taxation Research Journal, (07), 72-75.

McCutchen, W. W. (1993). Estimating the impact of the R\&D tax credit on strategic groups in the pharmaceutical industry. Research Policy, 22(4), 337-351. https://doi.org/10.1016/00487333(93)90004-2

Oliveira, F. G., \& Costa, L. (2013). The VAT Laffer Curve and the Business Cycle in the EU27: An Empirical Approach. Economic Issues Journal Articles, 20(2), 29-43.

Piotroski, J.D.,\&Wong,T.J.(2012). Institutions and Information Environment of Chinese Listed Firms. In Capitalizing China (pp. 201-246). https://doi.org/10.7208/9780226237268-007

Raffo, J., Lhuillery, S., \& Miotti, L. (2008). Northern and southern innovativity: A comparison across European and Latin American countries. The European Journal of Development Research, 20(2), 219-239. https://doi.org/10.1080/09578810802060777

Rajagopal, D., \& Shah, A. (1995). A rational expectations model for tax policy analysis: An evaluation of tax incentives for the Textile, Chemie, and Pharmaceutical Industries of Pakistan. Journal of Public Economics, 57(2), 249-276. https://doi.org/10.1016/00472727(94)01448-w

Rauch, J. E. (1991). Productivity Gains from Geographic Concentration of Human Capital: Evidence from the Cities (NBER Working Paper No. w3905). Cambridge, MA: National Bureau of Economic Research. https://doi.org/10.3386/ w3905

Ritter, T., \& Gemünden, H. G. (2004). The impact of a company's business strategy on its technological competence, network competence, and innovation success. Journal of Business Research, 57(5), 548-556. https:// doi.org/10.1016/s0148-2963(02)00320-x
Shahzad, F., Lu, J., \& Fareed, Z. (2019). Does the firm life cycle impact corporate risk-taking and performance? Journal of Multinational Financial Management, 51, 2344. https://doi.org/10.1016/j.mulfin.2019.05.001

Solow, R. M. (1957). Technical Change and the Aggregate Production Function. The Review of Economics and Statistics, 39(3), 312-320. https://doi.org/10.2307/1926047

Swenson, C. W. (1992). Some tests of the incentive effects of the research and experimentation tax credit. Journal of Public Economics, 49(2), 203-218. https://doi. org/10.1016/0047-2727(92)90020-g

Thomson, R. (2010). Tax Policy and R\&D Investment by Australian Firms. Economic Record, 86(273), 260-280. https://doi. org/10.1111/j.1475-4932.2010.00636.x

Wang, X. R., \& Wang, X. L. (2009). Research on the correlation between income tax and R\&D investment of high-tech enterprises. Public Finance Research, (05), 18-21.

Yang, Y., Cao, L. Y., \& Du, J. (2013). The influence of enterprise income tax preferential policies on the expenditure of R\&D - an empirical analysis based on the data GEM companies. Taxation Research, (03), 24-28.

Zhang, J. R., Chen, Y. X., \& Wang, F. J. (2016). Impact of preferential income tax policy on firms' innovation efficiency. Science Research Management, 37(03), 93-100.

Zhao, J. (2019). Research on Tax Planning Scheme of High-tech Enterprises. Marketing Management Review, (11), 18-20.

Zhou, H. (2012). The Impact of Preferential Tax Policy on Technology Innovation - Based on the Listed Companies in China. Reformation \& Strategy, 28(08), 67-70.

Zhu, L., Chen, X., \& Wang, C. Y. (2019). Research on the Influence of Mixed Reform of State-owned Enterprises on Corporate Innovation. Business Management Journal, 1-20.

Zhu, Q. Y. (2019). Encouraging Effects of Income Tax Incentives on Corporate R\&D Inputs - an empirical study on publicly-listed IT companies. Tax and Economic Research, 24(02), 18-28. 